\title{
Effects of Lysine and Methionine Concentration in Diet on Performance, Slaughter Variables and Serum Biochemical Profile in Slow Growing Chicks fed Rice Based Distillery Dried Grain with Solubles
}

M.V.L.N. Raju, B. Prakash, S.V. Rama Rao, A. Kannan, S.S. Paul

10.18805/IJAR.B-4774

\begin{abstract}
Background: The feeding value of rice-distillery dried grain with solubles (r-DDGS) for dual-purpose chicks was assessed in two feeding experiments.

Methods: Day-old Srinidhi chicks $(n=360)$ were divided into 6 equal groups with 10 replicates of 6 chicks each and fed r-DDGS at 0 or $15 \%$ in diet alongwith normal $(100 \%)$ or higher (110 and $120 \%$ ) concentration of lysine (Lys) and methionine (Met) individually (experiment 1). In the $2^{\text {nd }}$ experiment, day-old Vanaraja chicks ( $\left.n=390\right)$ were divided into 5 equal groups with 13 replicates of 6 chicks each and fed r-DDGS at 0 or $15 \%$ in diet alongwith normal $(100 \%)$ or higher $(110 \%)$ concentration of Lys and Met, either individually or in combination.

Result: Rice-DDGS significantly $(\mathrm{P} \leq 0.05)$ depressed body weight $(\mathrm{BW})$, which was totally countered by Met at $110 \%$ concentration (expt. 1). In the expt. 2, r-DDGS showed no effect on BW and FCR, except at 4 weeks, where FCR was similar in the control and the $110 \%$ Met groups. Abdominal fat content decreased in the r-DDGS groups with excess Met concentration (110\%) in diet. It is concluded that Met in excess $(110 \%)$ of normal concentration enabled inclusion of r-DDGS at $15 \%$ in the diet of dual-purpose chicks.
\end{abstract}

Key words: Lysine, Methionine, Rice-DDGS, Slow growing chicks.

\section{INTRODUCTION}

Rice-based distillers dried grain with solubles (r-DDGS) is a potential alternate protein source for use in the poultry diet. Corn-DDGS has been found to be a good source of protein in the diet of chickens (Raju et al., 2012). Rice-based DDGS ( $r-D D G S)$, on the other hand, is less researched upon, though it is a good source of protein ( $48.4 \% \mathrm{CP}$ ) (Dey et al., 2019), amino acids (Xue et al., 2012) and other nutrients.

In a previous study conducted at this lab, r-DDGS could be fed to Vanaraja chicks upto $10 \%$ in diet without affecting performance, while beneficial effects on performance were observed at 5\% in diet (Raju et al., 2021). Similarly, in broiler chicken and layer chicken, r-DDGS was found safe at 10 and $7.5 \%$ in diet, respectively (Rama Rao et al., 2016; Singh et al., 2021), whereas $15 \%$ level significantly $(P \leq 0.05)$ depressed the layer performance (Rama Rao et al., 2016). Similar negative effects were observed with r-DDGS at $15 \%$ in broiler chicken (Dinani et al., 2018; 2019), while no detrimental effects were reported with 10\% r-DDGS in laying chickens (Gupta et al., 2018). Besides, beneficial effects of r-DDGS on immunity were observed at moderate levels in broiler (Dinani et al., 2018) and layer (Gupta et al., 2017) diets.

Poor amino acid digestibility (Kim et al., 2009) has been considered the main limiting factor for using DDGS at higher levels in chicken diet. Supplementation of critical amino acids like lysine and methionine at additional levels to diets containing higher levels of DDGS may counter this reduced
ICAR-Directorate of Poultry Research, Rajendranagar, Hyderabad500 030, Telangana, India.

Corresponding Author: M.V.L.N. Raju, ICAR-Directorate of Poultry Research, Rajendranagar, Hyderabad-500 030, Telangana, India. Email: mvinraju@gmail.com

How to cite this article: Raju, M.V.L.N., Prakash, B., Rao, S.V.R., Kannan, A. and Paul, S.S. (2022). Effects of Lysine and Methionine Concentration in Diet on Performance, Slaughter Variables and Serum Biochemical Profile in Slow Growing Chicks fed Rice Based Distillery Dried Grain with Solubles. Indian Journal of Animal Research. DOI: 10.18805/IJAR.B-4774.

Submitted: 14-09-2021 Accepted: 27-12-2021 Online: 09-02-2022

amino acid digestibility and thus improve performance of chickens. Unlike the corn-DDGS, no published report is available about the amino acid digestibility in r-DDGS. In the present study, the possible beneficial effects of supplementation of lysine and methionine over and above the normal allowances on dual-purpose chicks fed r-DDGS at a higher level (15\%) were evaluated during the nursery phase of rearing.

\section{MATERIALS AND METHODS}

The effect of r-DDGS inclusion in diet at $15 \%$ alongwith normal or higher concentration of lysine (Lys) and methionine (Met) on slow growing dual-purpose chicks 
meant for backyard farming was evaluated in 2 feeding experiments during July-December 2019 at ICARDirectorate of Poultry Research, Hyderabad, India.

\section{Rice-DDGS samples and experimental diets}

The r-DDGS was procured from a local source (M/s Haritha Bio Products India Pvt. Ltd, Karimnagar, Telangana, India) and analysed for proximate composition (AOAC, 2016). The amino acid profile of r-DDGS was analysed employing wet chemistry (courtesy Evonik, Mumbai, India). A maize - soya bean meal based diet was compounded to serve as the control, whereas another set of experimental diets was formulated to contain r-DDGS at $15 \%$ in diet. In this set of experimental diets containing r-DDGS, Lys and Met were maintained at normal (100\%) or higher levels (110 and $120 \%$ of that of normal levels) (experiment 1) (Table 1).

In the $2^{\text {nd }}$ experiment, r-DDGS was included in diet at $15 \%$ and evaluated with normal $(100 \%)$ or higher levels (110\% of that of normal levels) of Lys and Met, either singly or in combination, thus forming a total of 5 experimental diets including one maize-soyabean meal based control diet (Table 1). All the diets were maintained isocaloric and isonitrogenous.

\section{Chicks and management}

The chicks used in both the experiments were slow growing dual-purpose type multi coloured chickens developed by ICAR-DPR for rural poultry farming. In the $1^{\text {st }}$ experiment, a total of 360 day-old Srinidhi chicks were divided into 6 groups with 10 replicates of 6 chicks each, while in the $2^{\text {nd }}$ experiment, a total of 390 day-old Vanaraja chicks were divided into 5 groups with 13 replicates of 6 chicks each and housed in raised wire floor SS battery brooders. The diets were fed ad libitum from 0 to 6 weeks of age.

\section{Data collection}

The effect of r-DDGS on body weight, feed intake and FCR (feed/body weight gain) was assessed at weekly intervals. At 6 weeks of age, about two to three $\mathrm{ml}$ of blood was collected through the brachial vein from one chick in each replicate (10 and 13 chicks per treatment in experiments 1 and 2 , respectively) into non-heparinised tubes. Subsequently, serum was separated and analysed for the concentrations of total protein (expts. 1 and 2) and cholesterol (expt. 2) using reagent kits (Qualigens, Mumbai, India). The antibody response to ND virus inoculation was assessed in terms of $\mathrm{HI}$ titres in expt. 1 during the last week of experiment in 10 chicks per each treatment group.

Further, one chick from each replicate was killed at the end of both the experiments and data on dressing yields and weights of visceral and lymphoid organs were recorded. Abdominal fat was collected as per Fancher and Jensen (1989). The weights were expressed as percent preslaughter live weight. The experiment was conducted as per the guidelines of the Institute's Animal Ethics Committee with the due approval.

\section{Statistical analysis}

The data were subjected to one-way analysis of variance under completely randomised design (Snedecor and Cochran, 1968) using SPSS software (version 15) and the means were compared by multiple range test (Duncan, 1955).

\section{RESULTS AND DISCUSSION}

In the expt. 1, r-DDGS significantly depressed body weight of chicks at 3 and 6 weeks of age (Table 2). Rice-based DDGS was found safe for broiler chicken upto $12.5 \%$, while

Table 1: Ingredient and nutrient composition of the experimental diets (\%).

\begin{tabular}{|c|c|c|c|c|c|c|c|}
\hline DDGS $\%$ in diet & 0 & 15 & 15 & 15 & 15 & 15 & 15 \\
\hline AA $\%$ & 100 & 100 & 110 Lys & 120 Lys & 110 Met & 120 Met & 110 Lys+110 Met \\
\hline Expt./s & 1,2 & 1,2 & 1,2 & 1 & 1,2 & 1 & 2 \\
\hline Maize & 64.80 & 65.50 & 65.50 & 65.50 & 65.502 & 65.502 & 65.50 \\
\hline DORB & 9.29 & 9.172 & 8.963 & 8.849 & 8.999 & 8.925 & 8.89 \\
\hline r-DDGS & 0.00 & 15.00 & 15.00 & 15.00 & 15.00 & 15.00 & 15.00 \\
\hline Soyabean meal & 21.00 & 5.20 & 5.30 & 5.30 & 5.30 & 5.30 & 5.30 \\
\hline DL-Methionine & 0.18 & 0.063 & 0.063 & 0.064 & 0.136 & 0.21 & 0.137 \\
\hline L-Lysine $\mathrm{HCl}$ & 0.08 & 0.376 & 0.485 & 0.598 & 0.374 & 0.374 & 0.485 \\
\hline Constants* & 4.65 & 4.69 & 4.69 & 4.69 & 4.69 & 4.69 & 4.69 \\
\hline Total & 100.00 & 100.00 & 100.00 & 100.00 & 100.00 & 100.00 & 100.00 \\
\hline \multicolumn{8}{|l|}{ Nutrients } \\
\hline ME, kcal & 2808 & 2806 & 2804 & 2802 & 2805 & 2804 & 2803 \\
\hline $\mathrm{CP}$ & 16.03 & 16.01 & 16.02 & 16.00 & 16.03 & 16.01 & 16.01 \\
\hline Lysine & 0.876 & 0.875 & 0.962 & 1.050 & 0.875 & 0.875 & 0.962 \\
\hline Methionine & 0.438 & 0.394 & 0.394 & 0.395 & 0.466 & 0.538 & 0.466 \\
\hline TSAA & 0.713 & 0.712 & 0.712 & 0.712 & 0.784 & 0.856 & 0.784 \\
\hline
\end{tabular}

${ }^{*}$ contained salt, minerals, vitamins, toxin binder, coccidiostat and choline Lys: Lysine Met: Methionine. 
Effects of Lysine and Methionine Concentration in Diet on Performance, Slaughter Variables and Serum Biochemical Profile in....

Table 2: Effect of rice-DDGS in diet alongwith varied lysine (Lys) and methionine (Met) concentration on performance of Srinidhi chicks (expt.1).

\begin{tabular}{lccccccc}
\hline r-DDGS, 15\% & AA $\%$ & \multicolumn{2}{c}{ Body wt, g } & \multicolumn{2}{c}{ Feed intake, g } & \multicolumn{2}{c}{ FCR } \\
\cline { 3 - 7 } in diet & & Wk-3 & Wk-6 & $0-3$ wks & $0-6$ wks & $0-3$ wks & $0-6$ wks \\
\hline- & 100 & $274.1^{\mathrm{a}}$ & $710.0^{\mathrm{a}}$ & 422.3 & 1467.8 & $1.54^{\mathrm{c}}$ & $2.07^{\mathrm{b}}$ \\
+ & 100 & $247.4^{\mathrm{b}}$ & $643.2^{\mathrm{b}}$ & 401.7 & 1415.8 & $1.62^{\mathrm{b}}$ & $2.22^{\mathrm{a}}$ \\
+ & 110 Lys & $242.4^{\mathrm{b}}$ & $686.1^{\mathrm{ab}}$ & 402.9 & 1449.5 & $1.66^{\mathrm{b}}$ & $2.11^{\mathrm{ab}}$ \\
+ & 120 Lys & $242.2^{\mathrm{b}}$ & $679.3^{\mathrm{ab}}$ & 419.5 & 1438.4 & $1.73^{\mathrm{a}}$ & $2.12^{\mathrm{ab}}$ \\
+ & $110 \mathrm{Met}$ & $269.7^{\mathrm{a}}$ & $702.8^{\mathrm{a}}$ & 433.7 & 1484.0 & $1.61^{\mathrm{bc}}$ & $2.11^{\mathrm{ab}}$ \\
+ & $120 \mathrm{Met}$ & $260.0^{\mathrm{ab}}$ & $700.7^{\mathrm{a}}$ & 423.9 & 1459.9 & $1.63^{\mathrm{b}}$ & $2.09^{\mathrm{b}}$ \\
& P & $<0.001$ & 0.04 & 0.19 & 0.51 & $<0.001$ & 0.08 \\
& SEM & 2.85 & 6.54 & 4.23 & 10.42 & 0.01 & 0.02 \\
\hline
\end{tabular}

Means in a column having different superscripts differ significantly $(P<0.05)(n=10)$.

Table 3: Effect of rice-DDGS in diet alongwith varied lysine (Lys) and methionine (Met) concentration on slaughter and serum biochemical variables in Srinidhi chicks (expt.1).

\begin{tabular}{|c|c|c|c|c|c|c|c|}
\hline $\begin{array}{l}\text { r-DDGS, 15\% } \\
\text { in diet }\end{array}$ & $\begin{array}{l}\text { AA } \\
\%\end{array}$ & $\begin{array}{c}\text { RTC } \\
\%\end{array}$ & $\begin{array}{l}\text { Liver } \\
\%\end{array}$ & $\begin{array}{c}\text { Giblets } \\
\%\end{array}$ & $\begin{array}{c}\text { Abd. fat } \\
\%\end{array}$ & $\begin{array}{c}\text { ND titres, } \\
\log 2\end{array}$ & $\begin{array}{c}\text { Serum } \\
\text { protein, } \mathrm{g} \%\end{array}$ \\
\hline- & 100 & 62.5 & 2.20 & 0.55 & 5.81 & 6.10 & 4.00 \\
\hline+ & 100 & 61.7 & 2.23 & 0.54 & 5.69 & 6.00 & 3.47 \\
\hline+ & 110 Lys & 61.8 & 2.30 & 0.53 & 5.67 & 6.20 & 3.62 \\
\hline+ & 120 Lys & 62.2 & 2.14 & 0.52 & 5.74 & 6.30 & 3.13 \\
\hline+ & 110 Met & 62.4 & 2.14 & 0.56 & 6.09 & 5.90 & 3.51 \\
\hline \multirow[t]{3}{*}{+} & $120 \mathrm{Met}$ & 63.3 & 2.12 & 0.56 & 5.93 & 5.90 & 3.42 \\
\hline & $P$ & 0.91 & 0.53 & 0.90 & 0.64 & 0.90 & 0.56 \\
\hline & SEM & 0.42 & 0.03 & 0.01 & 0.08 & 0.11 & 0.13 \\
\hline
\end{tabular}

$\mathrm{n}=10$.

at further higher level of $15 \%$, significant depression in growth was reported (Dinani et al., 2019), but when used at $12.5 \%$ in combination with rice gluten meal (15\%) adverse effects were noticed on the intestinal histomorphometry and microbiology (Dinani et al., 2018). Lysine concentration at either 110 or $120 \%$ of normal (100\%) level showed no effect on body weight at 3 weeks, whereas Met supplementation over and above the normal concentration significantly $(P \leq 0.05)$ improved body weight, which was on par with that of control group at $110 \%$ and the body weight at $120 \%$ Met concentration was intermediate between control and r-DDGS with normal amino acid level (100\%) groups. At 6 weeks of age, body weight of chicks fed r-DDGS was significantly $(P \leq 0.05)$ improved at 110 and $120 \%$ Met concentration, while the response with Lys supplementation in excess was intermediate. Kim et al. (2009) recorded low standardised ileal digestibility of all the indispensable amino acids in cornDDGS in comparison to soyabean meal in pigs. In broiler chickens, apparent ileal digestibility of Lys and Met was reduced with corn-DDGS inclusion in diet (Foltyn et al., 2014).

Amino acids in DDGS are known to be less digestible to chickens causing their deficiency when DDGS is used in diet (Stein et al., 2006). Thus the poor growth rate observed in the current study with $15 \%$ r-DDGS alongwith the improvement recorded with amino acid supplementation over and above the normal levels could be attributed to the low amino acid digestibility of r-DDGS, more particularly that of Met. Lysine digestibility of corn-DDGS was reported to be similar to that of corn in broiler chicks (Lumpkins and Batal, 2005), which could probably explain the reasons for lack of response to Lys supplementation as recorded in the current study. On the contrary, Fastinger et al. (2006) found decreased Lys availability in dark colored corn-DDGS, indicating the negative effects of excess heating during drying on the Lys availability in roosters. These conflicting results could be due to the differences in source of raw material used (Stein et al., 2006) and the process involved in the production of DDGS.

Feed intake was not affected at both 3 and 6 weeks of age. Feed conversion efficiency was significantly lowered by r-DDGS feeding at both 3 and 6 weeks of age, which could be attributed to its poor digestibility. Increased Met concentration in diets containing r-DDGS significantly $(P \leq 0.05)$ improved the feed conversion efficiency, which was similar to that of control group at both the ages. The dressing yields and weights of abdominal fat and organs were not affected (Table 3 ). Similarly, the serum total protein concentration and $\mathrm{HI}$ titres against ND virus were also not affected by the experimental diets.

In the expt. 2, r-DDGS inclusion in diet at $15 \%$ significantly $(P \leq 0.05)$ reduced body weight of chicks at both 3 and 6 weeks of age (Table 4). Additional supplementation of Lys alone $(110 \%)$ did not improve body weight in the groups fed r-DDGS either at 3 or 6 weeks of age. However, Met concentration at $110 \%$ resulted in significantly $(P \leq 0.05)$ 
Effects of Lysine and Methionine Concentration in Diet on Performance, Slaughter Variables and Serum Biochemical Profile in ....

Table 4: Effect of rice-DDGS in diet alongwith varied lysine (Lys) and methionine (Met) concentration on performance of Vanaraja chicks (expt.2).

\begin{tabular}{|c|c|c|c|c|c|c|c|}
\hline \multirow{2}{*}{$\begin{array}{l}\text { r-DDGS, } 15 \% \\
\text { in diet }\end{array}$} & \multirow{2}{*}{ AA $\%$} & \multicolumn{2}{|c|}{ Body wt., g } & \multicolumn{2}{|c|}{ Feed intake, $\mathrm{g}$} & \multicolumn{2}{|c|}{ FCR } \\
\hline & & Wk-3 & Wk-6 & $0-2$ wks & $0-6$ wks & $0-3$ wks & $0-6$ wks \\
\hline- & 100 & $325.2^{\mathrm{a}}$ & $932.2^{\mathrm{a}}$ & $248.0^{\mathrm{b}}$ & 1886.3 & $1.79^{d}$ & $2.10^{\mathrm{b}}$ \\
\hline+ & 100 & $314.0^{\mathrm{b}}$ & $891.1^{\mathrm{b}}$ & $265.1^{\mathrm{a}}$ & 1911.6 & $1.92^{a}$ & $2.23^{a}$ \\
\hline+ & 110 Lys & $312.8^{b}$ & $901.9^{b}$ & $260.1^{a}$ & 1887.9 & $1.90^{\mathrm{ab}}$ & $2.18^{\mathrm{ab}}$ \\
\hline+ & $110 \mathrm{Met}$ & $325.3^{a}$ & $915.3^{\mathrm{ab}}$ & $260.7^{\mathrm{a}}$ & 1862.3 & $1.82^{\mathrm{cd}}$ & $2.12^{\mathrm{b}}$ \\
\hline \multirow[t]{3}{*}{+} & 110 Lys+110 Met & $321.8^{\mathrm{ab}}$ & $915.0^{\mathrm{ab}}$ & $262.3^{a}$ & 1855.4 & $1.85^{\mathrm{bc}}$ & $2.11^{\mathrm{b}}$ \\
\hline & $\mathrm{P}$ & 0.02 & 0.04 & 0.05 & 0.71 & 0.001 & 0.006 \\
\hline & SEM & 1.64 & 4.47 & 1.93 & 13.45 & 0.01 & 0.01 \\
\hline
\end{tabular}

Means in a column having different superscripts differ significantly $(P<0.05)(n=13)$.

Table 5: Effect of rice-DDGS in diet alongwith varied lysine (Lys) and methionine (Met) concentration on slaughter and serum biochemical variables in Vanaraja chicks (expt. 2).

\begin{tabular}{lcccccccc}
\hline $\begin{array}{l}\text { r-DDGS, 15\% } \\
\text { in diet }\end{array}$ & AA\% & RTC, \% & Liver, \% & Giblet, \% & Abd. fat, \% & Spleen, \% & $\begin{array}{c}\text { Serum total } \\
\text { protein, } \\
\text { g\% }\end{array}$ & $\begin{array}{c}\text { Serum } \\
\text { cholesterol, } \\
\text { mg } \%\end{array}$ \\
\hline 0 & 100 & 58.9 & 2.05 & 4.83 & $1.94^{\mathrm{c}}$ & $0.22^{\mathrm{abc}}$ & 4.73 & 122.8 \\
- & 100 & 58.0 & 2.11 & 4.80 & $2.70^{\mathrm{a}}$ & $0.27^{\mathrm{a}}$ & 5.24 & 119.7 \\
+ & 110 Lys & 59.9 & 1.99 & 4.66 & $2.45^{\mathrm{ab}}$ & $0.20^{\mathrm{bc}}$ & 5.21 & 128.4 \\
+ & 110 Met & 61.6 & 2.01 & 4.76 & $2.08^{\mathrm{bc}}$ & $0.17^{\mathrm{c}}$ & 5.08 & 119.6 \\
+ & 110 Lys + 110 Met & 60.4 & 1.91 & 4.71 & $1.80^{\mathrm{c}}$ & $0.24^{\mathrm{ab}}$ & 5.34 & 117.3 \\
& P & 0.29 & 0.32 & 0.89 & 0.002 & 0.01 & 0.16 & 0.43 \\
& SEM & 0.56 & 0.03 & 0.06 & 0.09 & 0.01 & 0.08 & 1.95 \\
\hline
\end{tabular}

Means in a column having different superscripts differ significantly $(P<0.05)(n=10)$.

higher body weight of chicks at 3 weeks of age than that of non-supplemented r-DDGS group and comparable to that of the r-DDGS-free control group. However, effect of Met supplementation at excess level on BW was non-significant at 6 weeks of age. On the other hand, the body weight of chicks with Met supplementation at $110 \%$ in combination with Lys $(110 \%)$ at 3 weeks as well as at 6 weeks of age was intermediate between the non-supplemented r-DDGS fed group and the control (no r-DDGS) group and comparable to that of the Met alone group indicating no added advantage of Lys supplementation over and above the normal level of supplementation. Feed intake at 2 weeks was significantly $(\mathrm{P} \leq 0.05)$ higher in the groups fed $r$-DDGS compared to control and the additional supplementation of Lys and Met showed no effect.

Feed conversion efficiency was significantly $(P \leq 0.05)$ poor with r-DDGS alongwith normal Lys and Met concentration. Methionine supplementation at $110 \%$ either alone or in combination with Lys significantly $(P \leq 0.05)$ improved FCR, which was comparable with that of control at 3 weeks and on par with control at 6 weeks of age. The results indicate beneficial effects of excess Met supplementation on feed conversion efficiency in the chicks fed r-DDGS, whereas supplementation of Lys alone at additional level showed only marginal improvement in FCR. As detailed earlier in the paper, the improved growth rate and feed conversion efficiency recorded in the study with
Met supplementation in excess were probably due to the poor digestibility of r-DDGS in chicks.

Dressing yields and weights of organs were not affected, except for abdominal fat and spleen weight (Table 5). Abdominal fat content increased with r-DDGS feeding and Met supplementation $(110 \%)$ significantly $(P \leq 0.05)$ decreased to a level, which was similar (when supplemented alone) or comparable (in combination with Lys) to the control group. Increased abdominal fat content with r-DDGS was probably a result of impaired fat metabolism and Met in excess could counter the same through its role in limiting body fat deposition (Andi, 2012) by way of reducing the activity of fatty acid synthase (lipogenesis) and increasing the activity of hormone sensitive lipase (lipolysis) (Takahashi and Akiba, 1995). Spleen weight, though was significantly affected, no trend could be observed. Serum concentration of total protein and cholesterol was not affected by the dietary treatments.

\section{CONCLUSION}

The results of both the experiments indicate negative effects of r-DDGS on growth performance and feed conversion efficiency in slow growing dual-purpose chicks during the juvenile phase and Met supplementation in excess (110$120 \%$ ) of the normal concentration could successfully counter the same, while Lys in excess concentration (110$120 \%$ ) only showed marginal beneficial effects. 


\section{REFERENCES}

Andi, M.A. (2012). Effects of additional DL-methionine in broiler starter diet on blood lipids and abdominal fat. African Journal of Biotechnology. 11: 7579-7581.

AOAC. (2016). Official Methods of Analysis. Association of Official Analytical Chemists, $20^{\text {th }}$ Edn, Washington, DC.

Dey, D., Sharma, B., Mohammad, A., Mandal, D.K., Bhakat, C., Dutta, T.K. and Chatterjee, A. (2019). Effect of feeding rice distillers dried grain with solubles as major protein source on nutrient digestibility and growth performance of Jersey crossbred calves. Indian Journal of Animal Research. DOI: 10.18805/ijar.B-3788.

Dinani, O.P., Tyagi, P.K., Mandal, A.B., Tyagi, P.K. and Dutta, N. (2019). Evaluation of feeding value of rice based distillers dried grains with solubles (DDGS) for broiler chickens. Indian Journal of Animal Research. 53: 901-906.

Dinani, O.P., Tyagi, P.K., Mandal, A.B., Tyagi, P.K., Bhanja, S.K. and Popat, D.S. (2018). Effect of feeding rice based distillers dried grains with solubles (rDDGS) on gut health, immunity and intestinal histomorphometry in broilers. International Journal of Pure and Applied Biosciences. 6: 99-106.

Duncan, D.B. (1955). Multiple range and multiple $F$ tests. Biometrics. 11: 1-42.

Fancher, B.I. and Jensen, L.S. (1989). Influence on performance of three to six week old broilers of varying dietary protein contents with supplementation of essential amino acid requirements. Poultry Science. 68: 113-123.

Fastinger, N.D., Latshaw, J.D. and Mahan, D.C. (2006). Amino acid availability and true metabolizable energy content of corn distillers dried grains with solubles in adult cecectomized roosters. Poultry Science. 85: 1212-1216.

Foltyn, M., Lichovnikova, M., Rada, V. and Musilova, A. (2014). Apparent ileal amino acids digestibility of diets with graded levels of corn DDGS and determination of DDGS amino acids digestibility by difference and regression methods in broilers. Czech Journal of Animal Science, 59: 164-169.

Gupta, S.L., Tyagi, P.K., Mandal, A.B. and Tyagi, P.K. (2018). Evaluation of rice based dry distillers grains with soluble and its impact on egg cholesterol, sensory attributes, serum biochemical and hematological profile in laying hens. Veterinary Practitioner. 19: 138-143.
Gupta, S.L., Tyagi, P.K., Tyagi, P.K., Mandal, A.B., Kolluri, G., Mir, N.A. and Khan, A. (2017). The response of rice based dry distiller's grains with soluble (DDGS) feeding on gastrointestinal microbiota and immunity in layer's diet. Indian Journal of Poultry Science. 52: 133-137.

Kim, B.G., Petersen, G.I., Hinson, R.B., Allee, G.L. and Stein, H.H. (2009). Amino acid digestibility and energy concentration in a novel source of high-protein distillers dried grains and their effects on growth performance of pigs. Journal of Animal Science. 87: 4013-4021.

Lumpkins, B.S. and Batal, A.B. (2005). The Bioavailability of lysine and phosphorus in distillers dried grains with solubles. Poultry Science. 84: 581-586.

Raju, M.V.L.N., Rama Rao, S.V., Panda, A.K. and Shyam Sunder, G. (2012). Annual Report 2011-12. Project Directorate on Poultry. Hyderabad, India.

Raju, M.V.L.N., Rao, S.V.R. and Prakash, B. (2021). Performance, Serum Biochemical Profile, Slaughter Characteristics and Nutrient Retention of Vanaraja Chicks Fed Ricebased Distillers Dried Grains with Solubles in Diet. Indian Journal of Animal Research. 10.18805/IJAR. B-4190.

Rama Rao, S.V., Raju, M.V.L.N., Prakash, B., Reddy, E.P.K. and Anusha, R. (2016). Effect of dietary supplementation of distillery dried grain soluble from rice on performance of commercial broilers and White Leghorn layers. In: Proc. XXV World's Poultry Congress, Beijing. China: 52 (Abstr.).

Singh, L., Singh, U., Gupta, R. and Sethi, A.P.S. (2021). Effect of dietary inclusion of rice distillers dried grains with solubles with and without enzyme on growth performance and nutrient metabolizability of broilers. International Journal of Livestock Research. 11: 45-51.

Snedecor, G.W. and Cochran, W.G. (1968). Statistical Methods. $6^{\text {th }}$ Edn., lowa State University Press, Ames, USA.

Stein, H.H., Gibson, M.L., Pedersen, C. and Boersma, M.G. (2006). Amino acid and energy digestibility in ten samples of distillers dried grain with solubles fed to growing pigs. Journal of Animal Science. 84: 853-860.

Takahashi, K. and Akiba, Y. (1995). Effect of methionine supplementation on lipogenesis and lipolysis in broiler chickens. Journal of Poultry Science. 32: 99-106.

Xue, P., Dong, C.B., Zang, J.J., Zhu, Z.P. and Gong, L.M. (2012), Energy and standardized ileal amino acid digestibilities of Chinese distillers dried grains, produced from different region and grains fed to growing pigs. Asian-Australasian Journal of Animal Sciences. 25: 104-113. 